coloured suns all over the northern provinces of South America; while between the 3 rd and 4 th of the same month the glows extended across the Pacific both north and south as far as the Society and Gilbert Islands, and were reported from two stations in New Britain.

By September 5 the Sandwich Islands were reached; while the outburst of glows in Southern India did not commence till about the 6th to 8 th of the same month.

The northward extension of the dust all this time was very small, and not widespread. Isolated phenomena are reported from Formosa on August 26, and from Japan on the 28 th, but I am unable to say whether the glows which appeared in the Sandwich Islands on September 5, had come vici Japan, or across South America.

Thus the general system of the dust-flow appears to have been very simple. The great dust-stream was carried for the first twenty-four hours by the normal easterly upper currents over the south-east trade, at the extraordinary rate of more than 120 miles an hour, but hardly extended north of the line. Three days after the eruption we find the products of Krakatao in Guiana, the South Atlantic and also north of the line in the Cape Verd Islands. Just to the south of the latter we know that the south-east trade with its attendant upper currents crosses the equator. Then all the north of South America was invaded; and six or seven days after the first outburst, the Pacific Islands-south of, or on the linewere also overshadowed.

In fact we may say that the great stream of Krakatao dust was carried nearly round the world by the usual upper winds of the south-east trade, in which the dust was first ejected, at a rate of about 120 miles an hour, and that the dust spread very slowly either north or south of the main current.

There is one inference from this which is very important in any theory of the general circulation of the atmosphere from the equator to the Poles. The main body of the equatorial circulation is in an easterly direction, so that the whole mass of a $r$ going towards the doldrums does not rise up and flow backwards on itself directly towards the Pole; and though the highest currents over the Polar limit of both the south-east and north-east trades are from north-west and south-east respectively, still the poleward motion near the equator is very small.

The high velocity of 120 miles an hour is certainly more than would have been expected; but we have very few observations on the rate of motion of the highest clouds. Hildebrandsson has, however, reported from Upsala one velocity of about i 2 miles per hour for a cirrus at $\mathbf{2 8 , 0 0 0}$ feet (50 metres per second at 8559 metres); and several velocities ranging between that figure and 90 miles per hour.

There would be nothing, then, outrageous in the assumption of a velocity of 120 miles an hour for the easterly current over the equator to account for the high speed of the diffusion of Krakatao dust; and it is also satisfactory to know that the general direction of the flow is in accordance with the most recent researches on the vertical succession of the upper currents near the equator.

RALPH ABERCROMBY.

\section{BERNARD STUDER.}

$A$ MONG the magnates of Swiss geology, no name has held a more honoured place than that of Bernard Studer, who now at the ripe age of ninety-three years has passed away. Upwards of sixty years ago he began his scientific career by the study of some of the geological problems presented by the rocks of his native country. From the molasse of the lower grounds he soon climbed into the higher Alps, and distinguished himself as one of the foremost pioneers who grappled with the intricate problems in stratigraphy which these mountains present. With patient toil he extended year by year his acquaintance with the various portions of the chain, publishing from time to time notices of his labours, and preparing materials for a geological map of the whole region. In association with $\mathrm{A}$. Escher von der Linth he pursued these labours until the two fellow-workers were enabled to give to the world their great map of Switzerland, which, though only an outline of the geology of the Alps, will remain as an enduring monument of the geological prowess of its authors. No one who has not climbed the mountains with that map in hand can form any adequate conception of the physical labour, mental exertion, and happy geological intuition which its preparation required.

Studer's contributions to the glacial geology of the Alps brought him into intimate personal relations with many English geologists. All who passed through Berne tried to see the venerable Professor, who retained, in spite of his weight of years, his keen interest in the progress of his favourite science. His papers, published in various scientific journals, make a long list. But he was also the author of some separate works. Besides the great map of Switzerland, he published several volumes on Swiss geology, the most important of which was his "Geologie der Schweiz," which appeared in two volumes in $185 \mathrm{I}-53$. Less known perhaps, but full of suggestive matter, is his "Lehrbuch der physikalischen Geographie und Geologie," which was issued as far back as I844. This work was one of the earliest in which the processes of physical geography were discussed from the geological side, and showed how wide and thoughtful had been the observations of the author, especially among the phenomena to be witnessed in Switzerland. Another of the old lights of geology has been extinguished by the death of Bernard Studer, whose kindly presence and helpful courtesy will be affectionately remembered by everyone who has been fortunate enough to come in contact with him.

\section{NOTES.}

AN important Bill dealing with the question of technical education has been introduced into the House of Commons by Sir Henry Roscoe. The Bill empowers any School Board, loc a authority, or managsers of a public elementary school, to provide day technical and commercial schools and classes for the purpose of giving instruction in any of certain subjects. These include the several science subjects which are specified in the Directory of the Science and Art Department, and in which that Department undertakes to examine. The following subjects are also included: the use of ordinary tools, commercial arithmetic, commercial geography, book-keeping, French, German, and other foreign languages, and freehand and machine drawing. The addition of other subjects may be sanctioned from time to time by the Committee of Council on Education or by the Science and Art Department. For the purpose of carrying on these schools and classes, the power of School Boards, other local authorities, and school managers is to be in every respect the same as for providing ordinary elementary schools. They are to have power to provide, or contribute to the maintenance of, laboratories and workshops in endowed schools for the purpose of carrying on classes or instruction under the Bill. All these schools' and c'asses are to be subject to the inspect:on of the officers of the Committee of Eduction or of the Science and Art Department. Before a scholar is admitted he must have passed the Sixth Standard or some equivalent examination. The Education Committee and the Science and Art Department are authorized to give grants on such conditions as they may lay down for any of the subjects taught. For the purpose of obtaining grants a technical sch or class must be one carried on under minutes to be made by the 